\title{
ЕКОНОМІКА
}

$\begin{gathered}\text { Науковий вісник Нлту України } \\ \text { Scientific Bulletin of UNFU } \\ \text { https://nv.nltu.edu.ua }\end{gathered}$
$\begin{aligned} & \text { https://doi.org/10.36930/40290813 } \\ & \text { Article received 16.09.2019 p. } \\ & \text { Article accepted 31.10.2019 p. } \\ & \text { ISSN 2519-2477 (online) }\end{aligned}$
УДк 330.[341.1+342](477)

О. Ю. Клепанчук

Львівський національний університет ім. Івана Франка, м. Львів, Украӥна

\section{СТРУКТУРНІ КОМПОНЕНТИ ІННОВАЦЙНОЇ ТРАНСФОРМАЦІЇ ВІТЧИЗНЯНОЇ ЕКОНОМІКИ}

\begin{abstract}
Досліджено структурні складники інноваційної трансформації вітчизняної економіки. Показано, що формотворчі принципи концепції інноваційної трансформації реального сектора економіки України на сьогодні не сформульовані, тому в ролі моделі запропоновано адаптувати найближчі за змістовими характеристиками схеми. Відповідно до принципу системності, структурні компоненти визначено як сукупність взаємопов'язаних елементів зі спільною метою, ресурсним потенціалом та зовнішніми комунікаціями. Запропоновано ієрархічну декомпозицію цільових орієнтирів, розглянуто основні стратегічні пріоритети інноваційної трансформації вітчизняної економіки і визначено інструменти їх ефективного забезпечення. Доведено потреба розвитку виробничо-технологічної підсистеми, яка забезпечує подолання технологічного відставання вітчизняної економіки від світових економічних лідерів в умовах обмеженості бюджетних ресурсів. З'ясовано, що вирішення проблеми наукомісткості виробництва потребує узгодження державних механізмів податкового регулювання і розвитку науково-технічної діяльності. Описано закономірності дифузії інновацій, конвергенції технологічних платформ та поєднання технологій різних укладів. Визначено інтегратори та дестимулятори цих процесів. Запропоновано алгоритм побудови моделі інноваційної трансформації з покроковим описом здійснення послідовних етапів.
\end{abstract}

Ключові слова: економічні системи; інноваційні процеси; комунікації; ресурсний потенціал; стратегічні пріоритети; структурна трансформація; цільові орієнтири.

Вступ. Успішність розвитку вітчизняної економічної системи тісно пов'язана з активізацією високотехнологічного виробництва і створенням інноваційних продуктів. У Звіті про глобальну конкурентоспроможність 2017-2018 pp. Всесвітнього економічного форуму (World Economic Forum, 2018), згідно з яким Україна посіла лише 81 місце серед 137 досліджуваних країн, готовність до адаптації технологій та інновацій оцінено на рівні 81 місця. Незважаючи на значний науково-інтелектуальний потенціал, за показниками "Інновації" та "Іноземні інвестиції та трансфер технологій" Україна має доволі низький рейтинг.

Водночас, дані Global Innovation Index (Dutta et al., 2018) свідчать, що останніми роками Україна дещо покращила свої рейтингові позиції щодо інноваційного розвитку (2017 p. + 6 пунктів, 2018 р. + 7 пунктів), що зумовлено насамперед доволі високим співвідношенням отриманого економічного результату до інноваційних ресурсів. Зокрема у 2017 р. сектор інформаційних технологій продукував понад 3 \% ВВП, а сукупний дохід цієї галузі перевищив 80 млрд грн (State Statistics Service of Ukraine, 2019).

Розбудова інноваційного сектора нагально потребуе створення необхідних інституційних, наукових та еконо-

мічних передумов збалансованого розвитку вітчизняних суб'єктів господарської діяльності. Водночас, на законодавчому рівні чітко не визначені засади державної політики 3 питань підтримки інноваційної трансформації, що призводить до неефективності регулювання інституційного забезпечення інноваційного розвитку, неузгодженості програмно-цільового фінансування та відсутності чітких критеріїв підтримки у сфері інноваційної діяльності та трансферу технологій (Vasyltsiv et al., 2019). Отож, за таких умов надзвичайно актуалізуються питання глибинного аналізу структурного наповнення інноваційної трансформації національної економіки.

Аналіз наукових досліджень. Забезпечення інноваційної складової економічного прориву держави визнають сучасні дослідники принципово важливим питанням, у межах якого інноваційна перебудова спрямовується на максимальне використання результатів науково-технологічної сфери у бізнесі (Vasylenko \& Loktionova, 2018; Vasyltsiv et al., 2019; Sobko \& Zhyhalkevych, 2018).

Інноваційна розбудова вітчизняної економіки є багатоаспектним явищем, іiї специфічні прояви дослідники диференціюють за масштабом та якістю захищеності, за рівнем невизначеності та забезпечення, за можливостя-

\section{Інформація про авторів:}

Клепанчук Ольга Юріївна, канд. екон. наук, доцент, кафедра державних та місцевих фінансів. Email: o.klepanchuk@gmail.com; https://orcid.org/0000-0002-3099-6449

Цитування за ДСту: Клепанчук О. Ю. Структурні компоненти інноваційної трансформації вітчизняної економіки. Науковий вісник НЛТУ України. 2019, т. 29, № 8. С. 79-83.

Citation APA: Klepanchuk, O. Yu. (2019). Structural components of the innovative transformation of the domestic economy. Scientific Bulletin of UNFU, 29(8), 79-83. https://doi.org/10.36930/40290813 
ми управління, за сферами прояву та динаміки (CrespinMazet et al., 2019). Управління інноваційним оновленням пов'язане із застосуванням адаптивної, реактивної чи випереджаючої стратегій та орієнтується на простий чи розширений розвиток підприємств різних секторів економіки.

Еволюція підходів від концепції науково-технічного до інноваційного розвитку економіки спричинена необхідністю врахування мікроекономічної ініціативи (Furman et al., 2002). Позиціонування вектора розвитку економіки в напрямі Innovation-driven 3 метою досягнення та підтримки конкурентоспроможності тим більше вимагає інтернаціоналізації, кластеризації та посилення інтеграційних процесів, що потребує концептуальних змін у розрахунках рівня інноваційної трансформації економіки (Midler, 2019). Офіційна методика оцінювання рівня інноваційного розвитку вітчизняної економіки враховує макроекономічну, фінансову, зовнішньоекономічну, інвестиційну, науково-технологічну, енергетичну, виробничу, демографічну, соціальну та продовольчу складові (State Statistics Service of Ukraine, 2019). Водночас, не повністю коректним вважаємо стереотип пріоритетності макроекономічного підходу, що проявляється у домінуванні науково-дослідної сфери державних інституцій на противагу інноваційній активності бізнес-структур. На наш погляд, у сучасному періоді розвитку економіки експорт технологій дає змогу активізувати виробничі чинники, хоча і посилює ризики. Зазначимо, що в державних документах інноваційна перебудова економіки на макро- і мезорівнях трактується 3 наголошенням на створенні інноваційної інфраструктури та адекватних інноваційних механізмів (Cabinet of Ministers of Ukraine, 2019). Натомість донині як на державному рівні, так і в наукових дослідженнях не визначено структурованої характеристики інноваційної трансформації економіки, що зумовлює актуальність обраної проблематики.

Постановка завдання дослідження. Поглибити теоретичні та прикладні засади структурування інноваційної трансформації вітчизняної економіки з визначенням цільових орієнтирів і етапів побудови моделі інноваційної трансформації.

Об'єкт дослідження - теоретико-методологічні та науково-прикладні засади управління інноваційною розбудовою економіки.

Предмет дослідження - процеси моделювання формотворчих принципів інноваційної трансформації.

Мета дослідження - розроблення та обгрунтування моделі трансформації реального сектора економіки 3 урахуванням цільових орієнтирів підтримки рівноваги в системі економічного розвитку України.

Викладення основного матеріалу дослідження. Термінова потреба створювати інноваційну модель розвитку вітчизняної економіки за рахунок власних внутрішніх можливостей зумовлює втручання держави у ці процеси. Так, з метою підвищення ролі науки в розвитку сучасного суспільства державні інституції намагаються реалізувати неперервність "фундаментальні дослідження - прикладні дослідження - науково-технологічні розробки - інноваційне виробництво". Самоврядність наукових установ формує партнерську модель взаємовідносин між державою і науковим середовищем. Розробляються інтеграційні механізми імплементації вітчизняних інноваційних підприємств у міжнародний науковий процес, зокрема залучення до програм Європейського Союзу (Vasylenko \& Loktionova, 2018). На наш погляд, важливими аспектами є запровадження системи грантової підтримки проведення наукових досліджень та впровадження реального механізму захисту прав інтелектуальної власності. Активізація інноваційної діяльності вітчизняних підприємств створює передумови додаткової концентрації ресурсів для реалізації інноваційних пріоритетів розвитку економічної системи.

Формотворчі принципи концепції інноваційної трансформації реального сектора економіки України на сьогодні не сформульовані, тому в ролі моделі варто адаптувати найближчі за змістовими характеристиками схеми. Так, доцільно прийняти до уваги низку принципів побудови моделі інноваційної активності бізнесу (Bezus et al., 2018), окремі з яких (системності, цілісності, емерджентності та альтернативності), на наш погляд, достатньо повно можна використати для відповідного моделювання.

Системність, як принцип побудови трансформаційної моделі, полягає в тому, що її структурні компоненти розглядають як сукупність взаємопов'язаних елементів зі спільною метою, ресурсним потенціалом та зовнішніми комунікаціями. На інституційному рівні найважливішими елементами інноваційної трансформації економіки, на наш погляд, $є$ :

- стратегія науково-технологічного розвитку, державна політика у сфері наукової, науково-технічної та інноваційної діяльності;

- результативність вітчизняного сектора наукових досліджень і розробок, зокрема у сфері патентування і ліцензування;

- рівень інноваційної культури суспільства;

- паритет між галузевим і функціональним підходами до провадження інноваційної діяльності;

- стан інноваційної інфраструктури;

- підтримка вітчизняних виробників та експортерів інноваційної продукції на світовому ринку.

На жаль, сьогодні державне стимулювання інноваційного розвитку національної економіки обмежується лише формальними регуляторними способами впливу органів державного управління на поведінку суб'єктів інноваційної діяльності (рис. 1).

Цілісність процесу інноваційної трансформації потребує державного регулювання розвитку виробничотехнологічної підсистеми, що сприятиме подоланню технологічного відставання вітчизняної економіки від світових економічних лідерів. Натомість розвиток системи спрямовується переважно на підвищення конкурентоспроможності вітчизняної економіки, що потребує забезпечення системної координації діяльності органів влади і наукових інституцій без урахування специфіки окремих галузей і регіонів.

Виробничо-технологічна підсистема регулює інноваційну трансформацію шляхом забезпечення захисту прав інтелектуальної власності, сертифікації наукоємної продукції, надання послуг інформаційного спрямування. Повнота і функціональність виробничо-технологічної підсистеми забезпечують комплексність інноваційного процесу. Водночас, вирішення проблеми потребує узгодження державної фінансово-економічної і податкової політики 3 політикою науково-технічної та інноваційної діяльності. 
У побудові моделі інноваційної трансформації економіки принцип спадковості забезпечується інтеграційним розвитком з урахуванням загальних тенденцій та імперативів науково-технічного і соціально-економічного спрямування. Принцип емерджентності втілюється під час визначення цілей для системи управ- ління оновлення економічної системи загалом та її окремих компонент. На нашу думку, цілі інноваційної трансформації економіки мають бути ієрархічно диференційовані, що дасть змогу виокремити та систематизувати підцілі на кожному з рівнів (рис. 2).

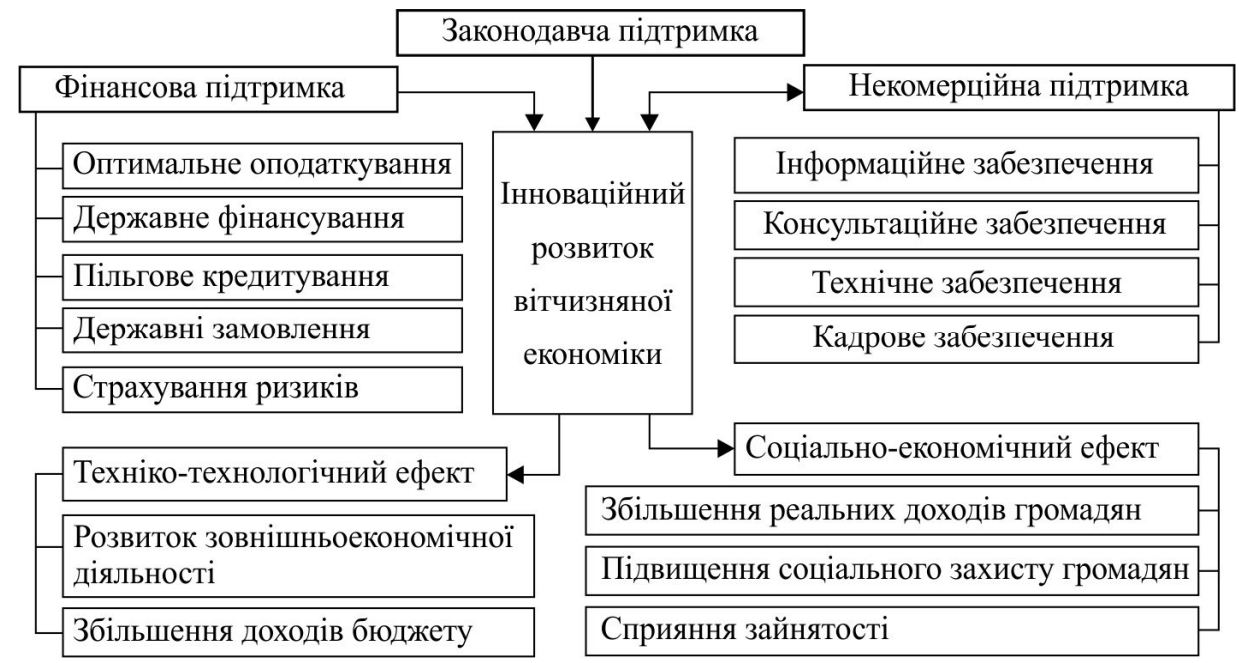

Рис. 1. Система державного стимулювання інноваційного розвитку економіки

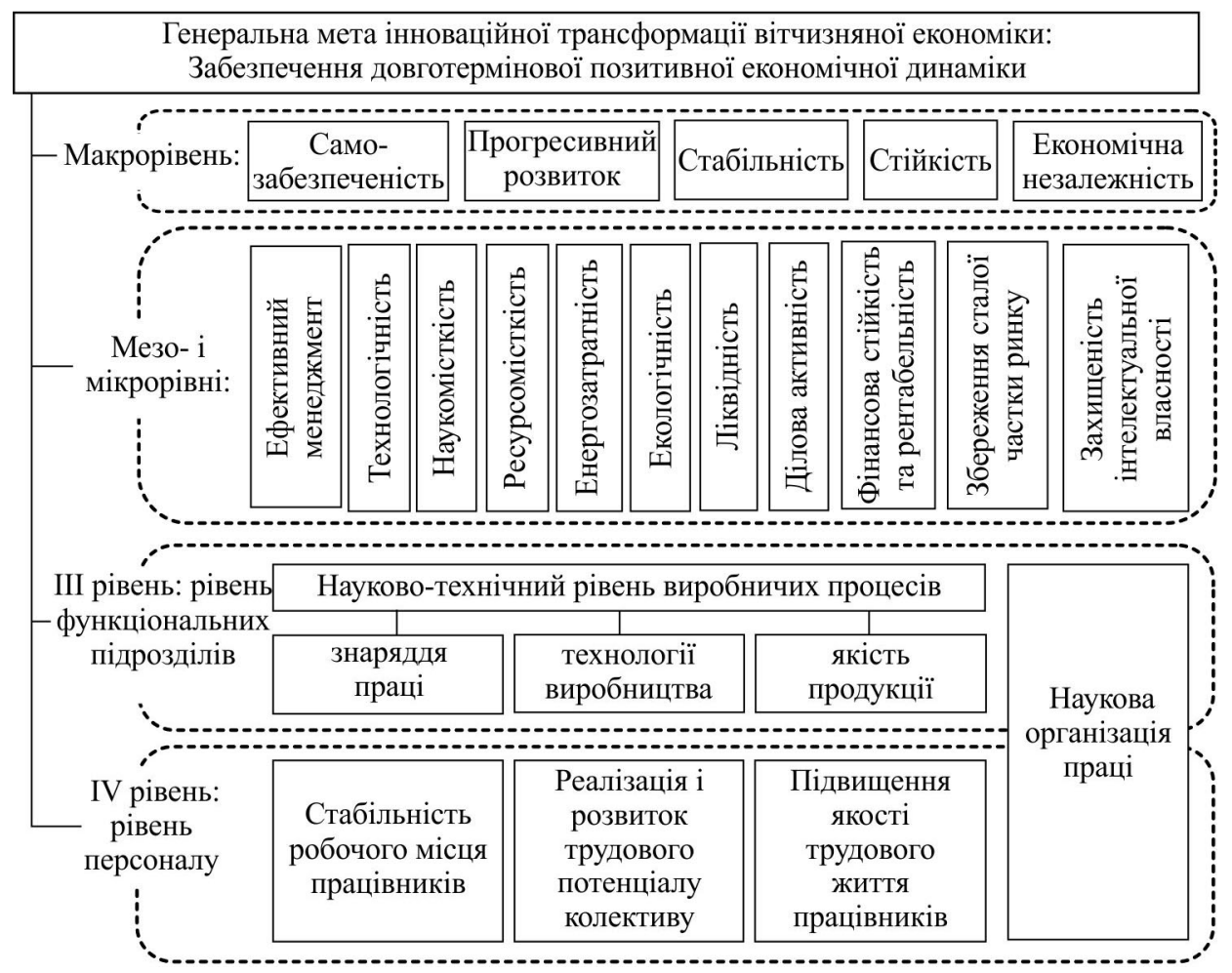

Рис. 2. Ієрархічна декомпозиція цілей інноваційної трансформації вітчизняної економіки

У стратегічному плані рівні економічного розвитку індивідуума, суб̆'єктів господарської діяльності й держави неподільні, оскільки як здійснення індивідуальних відтворювальних процесів, так і їхнє перетворення на процес суспільного відтворення можливі лише за умови їх органічного поєднання. Відтворення потребує від інноваційної організації участі у певному господарському процесі або входження у спеціальні інституційні відносини з державою. Внаслідок інтереси споживача потрапляють у пряму залежність від економічного розвитку як підприємця, так і держави. Перерозподіл суспільно корисного ефекту між виробниками і споживачами залежить від інформаційних процесів, потуж- ності комунікаційних каналів, можливостей практичного використання інноваційної продукції. Розвиток інноваційної економіки неможливий без вирішення інституціональних та ресурсних проблем фінансового, організаційно-правового, інформаційного та ринкового характеру. Відповідно до цього, ми систематизували цілі інноваційної трансформації на секторальному рівні:

• організаційно-комунікаційні: розвиток інноваційної інфраструктури, налагодження зв'язків з іншими суб'єктами інноваційного процесу з метою двосторонньої дифузії інновацій;

• інформаційні: доступність і відкритість інформаційних потоків;

- ринкові: зниження вартості нововведень, зменшення ризиковості інноваційної діяльності. 
Збереження стабільного поступального економічного розвитку суспільства грунтується на засадах національної системи управління інноваційною діяльністю (рис. 3), основним завданням якої є створення умов для конкурентоспроможності вітчизняних товаровиробни- ків шляхом технологічної модернізації, застосування передових технологій, методів організації та управління господарською діяльністю для забезпечення стабільного економічного зростання.

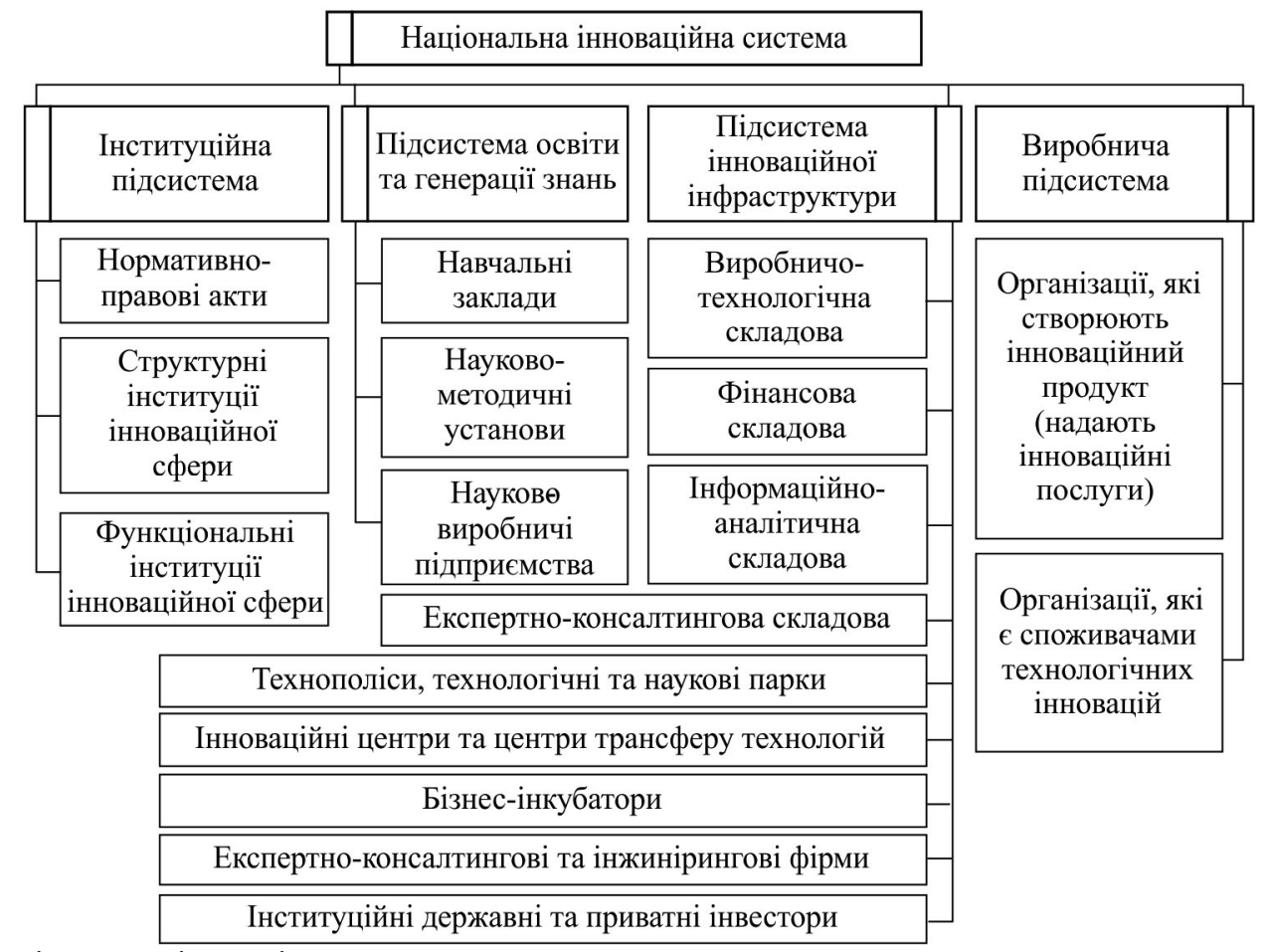

Рис. 3. Структура вітчизняної інноваційної системи

Для успішного функціонування внутрішніх механізмів забезпечення інноваційної трансформації важливою $\epsilon$ можливість вибору альтернативних шляхів інноваційного розвитку для їх узгодження з наявними інструментами державного регулювання. Отож, побудова моделі передбачає здійснення послідовних етапів. Передусім відбувається аналіз ринку технологій виробництва аналогічної продукції, застосовуваних технологічних процесів і пошук внутрішніх резервів удосконалення технологій. Також аналізується товарний ринок, перспективи реалізації продукції і прогнозується специфіка технологічних процесів виробництва конкурентоспроможного інноваційного продукту. Після розроблення технологічної стратегії і здійснення планів технологічного розвитку економіки аналізуються результати практичної реалізації заходів щодо забезпечення іiї технікотехнологічної складової.

У реальному соціально-економічному середовищі відбувається дифузія інновацій, коли нововведення передається комунікаційними каналами між членами соціальної системи. Дифузія науково-технічних розробок здійснюється також шляхом кооперування 3 партнерами, що дає змогу оптимізувати витрати завдяки вужчій спеціалізації. Водночас, спостерігається конвергенція технологічних платформ та поєднання технологій різних укладів. Для забезпечення високої результативності важливими є науково-технічна співпраця та підтримка, які реалізуються через участь бізнесу в дослідних програмах і технологічних альянсах, діяльність технопарків, технологічні гранти, що передбачає високу якість наукових досліджень і взаємодію підприємств, університетів та державних наукових установ.
Характер інноваційної системи держави визначається як формальним, так і неформальним законодавчими полями. Для підтримання належного рівня економічної безпеки держави у цьому сенсі істотним є дотримання правил і законів, якими регулюються відносини в процесі трансферу технологій. Некомерційне передавання інформації, що не є секретною та не підлягає патентуванню, можна розглядати як один із каналів трансферу. Тут варто відзначити обмін досвідом та спільне використання результатів досліджень вченими та спеціалістами підприємств, міграцію висококваліфікованого персоналу, науково-технічні публікації. Водночас, нелегальне використання науково-технологічних ресурсів у формі промислового шпигунства, підробки технологій і продукції $є$ значним негативним чинником забезпечення інноваційної складової економічного розвитку держави.

На постіндустріальному етапі суспільного розвитку виникають нові форми організації економічних систем, зокрема інтелектуальна, під якою розуміємо наявність знань, їх виробництво та відтворення. У цьому аспекті вважаємо за доцільне зазначити таке загрозливе явище, як міграція висококваліфікованого персоналу до центрів інноваційного розвитку. 3 огляду на оцінку ризиків, основна проблема полягає у виникненні дефіциту висококваліфікованих трудових ресурсів на рівні вітчизняних підприємницьких структур за неможливості своєчасного поповнення через відсутність дієвих систем мотивації.

Висновки. Основним завданням інноваційної трансформації вітчизняної економіки є створення сприятливих макроекономічних умов для інвестування у нововведення, усуванні структурних деформацій та формуванні сприятливого інституційного середовища. Прак- 
тичне значення для успішної реалізації інноваційної розбудови України мають рекомендації диференціювати структурні компоненти за рівнями ієрархії з відповідними об'єднувальними властивостями, що охоплюють законодавчу базу, фінансову підтримку, науковотехнічні розробки і техніко-технологічні процеси, що разом здатні забезпечити конкурентоспроможність інноваційної економіки. Механізм забезпечення трансформації має охоплювати інституціональну надбудову і внутрішні інструменти, спрямовані на підтримку рівноваги в системі економічного розвитку. Саме взаємодія цих механізмів здатна забезпечити адекватну відповідь на дію негативних зовнішніх впливів, деструктивних чинників і сприяти руху вітчизняної економічної системи до цільових орієнтирів. Варто продовжити науковий пошук із вивчення цієї проблеми 3 огляду на їі багатоаспектність і глибину.

\section{Перелік використаних джерел}

Bezus, A. M., Shafranova, K. V., \& Bezus, P. I. (2018). Role of innovation development in enterprise sustainability. Investytsii: praktyka ta dosvid, 8, 22-25. [In Ukrainian].

Crespin-Maze, F., Romestant, F., \& Salle, R. (2019). The co-development of innovative projects in CoPS activities. Industrial Marketing Management, 79, 71-83.

Dutta, S., Reynoso, R. E., Garanasvili, A., \& Saxena, K. (2018). The Global Innovation Index 2018. (Chapter 1: Energizing the World with Innovation). New York: Cornell University, INSEAD, WIPO, 52 p. Retrieved from: https://www.wipo.int/edocs/pubdocs/en/ wipo pub gii 2018-chapter1.pdf.

Furman, J. L., Porter, M. E., \& Stern, S. (2002). The determinants of national innovation capacity. Research Policy, 31, 899-933.
Kabinet Ministriv Ukrainy. (2019). Pro skhvalennia Stratehii rozvytku sfery innovatsiinoi diialnosti na period do 2030 roku: rozporiadzhennia № 526-r vid 10.08. 2019 r. Ofitsiinyi visnyk Ukrainy, № 5, 139, stattia 1983, kod akta 95224/2019. [In Ukrainian].

Midler, C. (2019). Crossing the Valley of Death: Managing the When, What, and How of Innovative Development Projects. Project Management Journal, 50(4), 447-459.

Sobko, O. Yu., \& Zhyhalkevych, Zh. M. (2018). Features of foreign experience of reengineering innovative activity of the enterprise. Suchasni pidkhody do upravlinnia pidpryiemstvom: zbirnyk naukovykh prats, 3, 324-332. [In Ukrainian].

State Statistics Service of Ukraine. (2019). Scientific and innovative activity of Ukraine - 2018: statistical collection. Kyiv: Derzhanalitinform, 108 p. [In Ukrainian].

Sustainable Development. (2018). Harnessing Frontier Technologies for Sustainable Development. Technology and Innovation Report 2018. Switzerland: United Nations Publication, $134 \mathrm{r}$.

UNCTAD. (2018). World Investment Report 2017: Investment and the Digital Economy. Retrieved from: https:/unctad.org/en/Pages/DIAE/World Investment Report/World Investment Report.aspx

Vasylenko, V. O., \& Loktionova, O. S. (2018). Innovative component of strategic management of foreign economic activity of the enterprise. Visnyk NTU "KhPI", 47(1323), 42-47. [In Ukrainian].

Vasyltsiv, T., Lupak, R., \& Zaichenko, V. (2019). Current Aspects of Increasing the Technological Competitiveness of the Real Sector of the Ukrainian Economy. Finansovo-ekonomichnyi rozvytok Ukrainy $v$ umovakh transformatsiinykh peretvoren: Proceedings of the International Scientific and Practical Conference, Lviv, Mart 28, 2019. (pp. 11-13). Ternopol: Krok, 195 p. [In Ukrainian].

World Economic Forum. (2018). Global Competitiveness Report 2017-2018. Retrieved from: https://www.weforum.org/reports/theglobal-competitiveness-report-2017-2018.

O. Yu. Klepanchuk

Ivan Franko National University of Lviv, Lviv, Ukraine

\section{STRUCTURAL COMPONENTS OF THE INNOVATIVE TRANSFORMATION OF THE DOMESTIC ECONOMY}

The need to achieve high competitiveness of the national economy requires the development of mechanisms that can harmonize qualitatively all the components of innovation, the direction of financial, technological and organizational resources of domestic business to ensure a high-tech breakthrough. The purpose of this article is to investigate and deepen the theoretical and applied principles of structuring the innovative transformation of the domestic economy with the definition of targets and the tools for their effective provision. Since the formative principles of the concept of innovative transformation of the real sector of the Ukrainian economy have not been formulated today, the schemes closest in meaning are suggested to be adapted as the model. The principle of heredity in modeling manifests itself through integration development, considering the general tendencies of its scientific, technical and socioeconomic trends. The principle of emergence is embodied in the definition of goals for the system of management of the economic system as a whole and its individual components. In accordance with the principle of systematicity, structural components are defined as a set of interconnected elements with common purpose, resource potential and external communications. The hierarchical decomposition of the targets is proposed, the main strategic priorities of the innovative transformation of the domestic economy are revealed, and the instruments for their effective provision are identified in the paper. The necessity of development of the production and technological subsystem, which ensures overcoming the technological backwardness of the domestic economy from the world economic leaders in the conditions of limited budget resources, has been proved. The solution of the problem of high technology of production is revealed to require coordination of state mechanisms of tax regulation and development of scientific and technical activity. The laws of diffusion of innovations, convergence of technological platforms and combination of technologies of different ways are described. The algorithm of construction of model of innovative transformation with step by step description of realization of successive stages is offered.

Keywords: economic systems; innovative processes; communication; resource potential; strategic priorities; structural transformation; targets benchmarks. 